investigations. This makes it impossible to predict which of the metals should be adsorbel on the surface. If wo assume, however, that the difference of surface tensions is the cause of highly selective oxidation of aluminium-beryllium and aluminium-magnesium nl. loys, it is to be inferred that the surface tension of magnesium and beryllium is much lower than that of aluminitum.

\section{S. DobiŃski.}

II. NiEsruchowski.

Institute of Experimental Physics,

University, Poznan. July 24.

'Preston, G. D., and Bircumshaw, L. L., Phil. Mag., 20, 706 (1935). ' litaka, I., and Mijake, S., Nattre, 136, 437 (193j); 137, 457 (1936).

- Doblński, S., Natcre, 141, 81 (1938) and Bull. Int. de l'Acad. Pol., 169 (1033).

- Dobiński, S., and Jagielski, A., Bull. Int. de l'Acad. I'ul., 424 (1933).

s Dobiński, S., and Grycza, J., Acta Physica Polonica, in the press.

\section{Extremely Bright Spots on Coolidge Tube Target}

WHILE making tests with a nowly mado Coolidgo tubo with molybdenum target, wo discovered soveral bright spots of unusual brightness on its target surfaco.

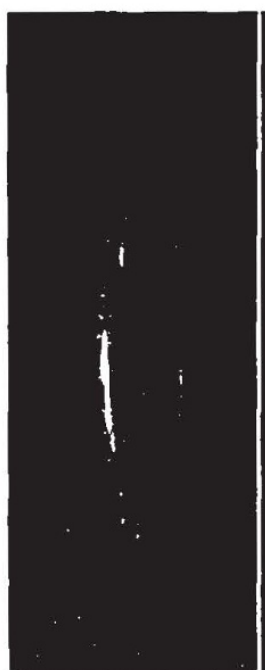

(a)

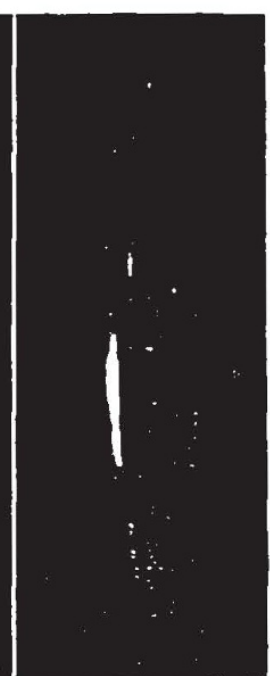

(b)
'The accompanying illustration shows $(a)$ photo. graphs of the target when only the cathode of the Coolidgo tubo was heated, that is, while the $\mathrm{X}$-rays wero not being radiated, and $(b)$ of tho samo target taken when a voltago of 50 -cyclo $40 \mathrm{kv}$. (peak value) was impressed on the anti-cathodo and an electronic current of $20 \mathrm{~mA}$. D.c. was flowing, that is, whilo $\mathrm{X}$-rays wero being radiated. In front of the lens of tho cnmera, a right-angled glass prism was attuched so as to prevent the X-rays being projected on the sensitized plate of the camera. In $(b)$ several white spots will be seen, whereas in (a) no such spots exist. Tho photograph does not show these spots well; tho actual bright spots glaro quite intensely and look as if they were embossed on the target surface. The target of the Coolidge tube was continuously cooled with running water.

In order to ascertain whether these bright spots were produced during the half-cycle in which the electronic current follows, or during the other half. cycle, a stroboscopic observation was made, and it was found that they wero produced only during the former half-cycle, and tho larger the instantaneous value of current the greater the intensity. Furthormore, when the heating current of the cathode was kept constant, thero was practically no change in the brightness of the spots, even when the anodo voltage was lowered to a voltage such as $10 \mathrm{kv}$. (peak value), at which no radiation of the characteristic $\mathrm{X}$-rays of molybdenum would talie place; but when the heating current was varied, tho brightness whs greatly affected, theso spots being nearly invisiblo when tho electronic current was less than $10 \mathrm{~mA}$.

From these results it would appear that the spots aro duo to electronic bombardment; in other words, due to a particularly intensified electric field at somo minute protrusions accidentally existing on the target surface, tho protruding points becomo incundescent. As clearly scen from the photographs, the surface of the target is not perfectly smooth; it is covered with scratches, as if tho surface had been brushed over. These fucts support the view put forward.

$$
\text { I. Koga. }
$$

II. TAтrBaxi.

Department of Electrical Engineering,

Tokyo University of İnginecring, Tokyo.

June 19.

A similar phenomenon to that described by Messrs. Koga and Tatibana has been observed during tho course of certain research work on multi-segment magnetrons operating under rather abnormal circuit arrangements at about $80 \mathrm{~cm}$. wave-length.

Brilliant points of luminescence havo been observed on the rear surfaces of the anodo segments, which aro each in the form of a hollow tantalum trianglo with one curved face receiving the electron stream, and generally running very hot, about yellow-white. The appearance of these spots of light was so distinctive that it was at first thought that holes had been formed in the anode rear surface, making visible the almost white-hot inner face. On examination, when not operating, it was seen that tho anodes wero not punctured, nor was it possiblo to account for such puncturing, although a 'cyclotron' effect has been observed giving a charge on a sereen surrounding the anodes four times the voltage applied to the anodes.

It was found that a high output was needed before tho spots appeared and the general order was about 400 watts radio frequency with the anodes dissipating about 175 watts. Furthermore, the spots wero critical with regard to filament cmission and also disappeared suddenly below 2,100 volts on the anodes, but were quite unchanged by largo variations of voltage above this : a fact which is noticed by the Japanese investigators.

I remember noting several years ago similar effects in a Farnsworth cold cathodo multiplier (photoelectric cathodes with focusing magnetic field) whero flash-overs kept occurring, maybe due to the liberation of gas from an almost microscopic incandescent protuberance.

Ultra.short Wave Laboratory, Jax Forman.

London Hospital Medical College,

Turner Street, London, F.l. 